\title{
Scientists
}

\section{Necessity is the mother of invention}

\author{
Piotr Chomczynski \\ Founder, President, and Director of R\&D, Molecular Research Center, Inc., Cincinnati, Ohio
}

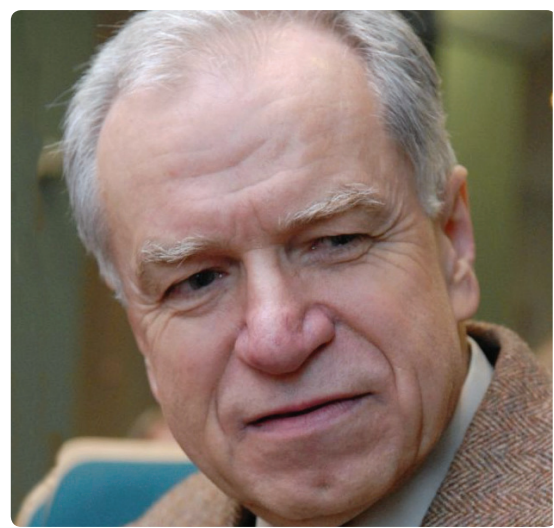

Piotr Chomczynski's development of one of the most frequently used techniques in molecular biology today, the single-step method of RNA extraction, caught our attention. Curious to know more, BioTechniques contacted him to find out about the ambition, character, and motivation that led to his success.

What motivated you to choose a career in science?

When I attended university in the 1960s, Poland was a communist country where everything was run by the government. While I was studying biochemistry, I noticed a certain kind of freedom in science and decided that I would like to spend my life doing research.

What has been your most significant contribution to your field?

My most significant scientific contribution is the development of different methodologies, particularly the single-step method of RNA isolation. After finishing my Ph.D., I began a postdoctoral fellowship at the NIH. At that time, RNA isolation required ultracentrifugation. But when I returned to Poland one year later, the government was not financing science so I did not have access to an ultracentrifuge. My colleagues in Poland and I saw the need to replicate research approaches on our own without using costly methodology, chemicals, and equipment. So, I began to invent new reagents and techniques to bypass the lack of machinery and financing in Polish laboratories.

\section{When did you permanently move to the United States?}

I returned to the United States in 1981-82 as a visiting scientist at NIH. At the end of that tenure, I had to decide whether to go back to Poland or stay here and look for new opportunities to work in the United States. The 1980 s were a really bad time for research in Poland; there was an economic downturn and social upheaval. I had established a Solidarity Chapter at the university and therefore was not very welcome in Poland. In the end, I found a position as a professor at the University of Cincinnati and decided to stay.

In the US, there are not only opportunities for basic science research, but also for building businesses related to science. This was a new avenue that I could not pursue in Poland. After the publication of our single-step RNA isolation method where I described how to make the reagents and every detail of the protocol, a colleague pointed out that I could patent this approach. I believed this was a way for my research to have an immediate impact, not something seen many years later, so I established my first company in Houston, Texas, to market a reagent called RNAzol for RNA isolation. During this time, I continued working as a professor during the week, but on weekends I flew to Houston to work on my business.

\section{At what point did you decide to focus exclusively on your business?}

When my NIH grant ended in 1994 , the chairman of my department asked to meet with me to make sure I knew my grant was ending and ask why he hadn't seen another grant application. I told him that I didn't need a grant because I would finance my laboratory through my business. He was surprised, but for me this was a very important moment - my business allowed me to do what I wanted to do in science without having to justify my ideas to gain funding. I financed my university laboratory for three years before deciding to focus entirely on research at my company, Molecular Research Center (MRC).

\section{What are you working on now?}

After making biochemical reagents for a number of years with MRC, I set out to do something entirely different. In Poland, I established the first TV station devoted to business. It was fun for me to be a scientist, a university professor, and run a fully developed TV station with multiple studios and 100 employees. But it grew so fast that I couldn't be both a scientist and businessperson, so four years ago I sold the station to a media corporation that continues its operations today in Poland.

Another project I am currently working on came about during my travels to Poland. While there, I often drink tomato juice, which is very healthy. I thought that I should try to drink it every day, but I did not care for the characteristic tomato taste. So, I decided to develop tomato juice with all the healthy properties, but without the tomato taste. After some development, I have patent pending technology for making tomato juice that is not genetically modified, but engineered using an old-fashioned approach to identify taste compounds and selectively extract them from the tomato paste. We end up with tomato concentrate without the tomato taste, and by adding apple juice to this, we create a drink that tastes like apple juice but has all the characteristic health components of tomato juice. I have a company producing this juice and selling it in Poland and Germany.

And of course, we are always working on new RNA isolation reagents. Two years ago, we updated our single-step reagent for use in reverse transcription PCR without the need for DNase treatment and we are also now using RNA sequencing to study certain disease models.

Interviewed by Kristie Nybo, Ph.D. Image courtesy of Judith Heiny. 䢐

BioTechniques 53:337 (December 2012)

doi 10.2144/000113959

To purchase reprints of this article, contact: biotechniques@fosterprinting.com 